\title{
Motion Simulation of FPSO in Waves through Numerical Sensitivity Analysis
}

\author{
Je-in Kim*, Il-Ryong Park ${ }^{*}$, Sung-Bu Suh, Yong-Duck Kang ${ }^{*}$, Sa-Young Hong ${ }^{* *}$ and Bo-Woo Nam ${ }^{* *}$ \\ "Department of Naval Architecture and Ocean Engineering, Dong-Eui University, Busan, Korea \\ "Korea Ocean Research \& Development Institute, Korea research Institute of Ship \& Ocean Engineering, Daejeon, Korea
}

\section{수치 민감도 해석을 통한 파랑중 FPSO운동 시뮬레이션}

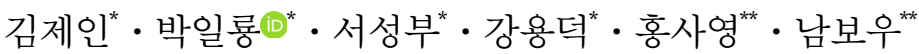 \\ "동의대학교 조선해양공학과 \\ "선박해양플랜트 연구소
}

KEY WORDS: Wave propagation 파진행, Motion 운동, CFD 전산유체역학, Numerical sensitivity 수치 민감도, Error distribution 오차분포

\begin{abstract}
This paper presents a numerical sensitivity analysis for the simulation of the motion performance of an offshore structure in waves using computational fluid dynamics (CFD). Starting with 2D wave simulations with varying numerical parameters such as grid spacing and CFL value, proper numerical conditions were found for accurate wave propagation that avoids numerical diffusion problems. These results were mapped on $2 D$ error distributions of wave amplitude and wave length against the numbers of grids per wave length and per wave height under a given CFL condition. Finally, the 2D numerical sensitivity result was validated through CFD simulation of the motion of a FPSO in waves showing good accuracy in motion RAOs compared with existing potential flow solutions.
\end{abstract}

\section{1. 서 론}

최근, 전산유체역학(Computational fluid dynamics, CFD)의 다양 한 해양공학문제에 적용, 큰 진폭의 비선형파(Nonlinear wave)에 의한 해양구조물의 파랑 충격력(Wave impact) 및 갑판침수(Green water)와 같은 현상을 보다 정확히 추정하기 위한 연구들이 활발하 게 진행되고 있다(Sato et al., 1999; Nielsen, 2003; Zhang et al., 2005; Yum and Yoon, 2008; Heo et al., 2011; Kim, 2011; Go et al., 2017; Nam et al., 2012; Park et al., 2013; Nam et al. 2017). CFD를 통해 파랑중 해양구조물 주위 유동에 대한 본격적인 해석에 앞서, 주어 진 파에 대한 시률레이션에서 수치감쇠(Numerical damping)를 감 소시키기 위한 적절한 수치 해석적 조건을 찾는 중요한 과정을 수행해야 한다. 관련된 수치 해석적 변수로는 계산영역의 크기, 격자수, 계산시간 간격 및 계산영역의 경계면에서 파의 반사를 피 하기 위한 소파(Wave absorption)방법 및 그 영역의 크기 등이 해당 된다. 물론 지배방정식의 공간과 시간에 대한 수치 이산화 기법과
자유수면 표현 기법의 정확도도 중요한 요소가 될 수 있다. 일반적 으로, 파랑중 해양구조물의 운동해석은 긴 계산시간을 요구하기 때문에 유동장의 크기, 격자수 및 계산시간 간격은 전체 계산시간 의 크기를 결정하는 중요한 요소가 된다. 앞서 본 논문에서는 CFD 기법이 큰 장점을 가지는 파와 구조물의 강한 비선형 상호작용 문제 해석에 앞서 해석해가 존재하는 문제를 먼저 다루고 그 결과 를 검증하는 것으로 한정하고자 한다. 수치해석 결과에서는 2 차원 비선형파 진행문제를 다루고 주어진 파조건에 대한 수치해의 정확 도를 유지하는데 필요한 격자수 및 계산시간 간격의 민감도를 조 사하였다. 여기서, 유동장의 하류에서 파를 소파시키기 위한 방법 의 경우는 최근 수행된 타 연구자의 결과를 적용하고 본 연구에서 검증한 결과를 소개하였다. 본 논문에서 얻은 파 진행문제에 대한 2 차원 수치 민감도 검토 결과는 3 차원 파랑중 $\mathrm{FPSO}$ (Floating production storage and offloading) 운동 문제에 적용하고 구조물의 운동을 타당하게 추정하는 데 필요한 수치 격자의 민감도를 검토 하였다.

Received 22 March 2018, revised 5 June 2018, accepted 7 June 2018

Corresponding author Il-Ryong Park: +82-051-890-2595, irpark@deu.ac.kr ORCID: https://orcid.org/0000-0002-6194-5716

It is noted that this paper is revised edition based on proceedings of KAOST 2017 in Busan.

(C) 2018, The Korean Society of Ocean Engineers

This is an open access article distributed under the terms of the creative commons attribution non-commercial license (http://creativecommons.org/licenses/by-nc/3.0) which permits unrestricted non-commercial use, distribution, and reproduction in any medium, provided the original work is properly cited. 


\section{2. 수치 해석 방법}

\section{1 지배방정식}

유동은 해석되는 문제에 따라 2 차원 비선형파 진행 문제의 경 우 비압축성 층류유동(Laminar flow)으로 가정하였으며, 파랑중 해양구조물 운동문제의 경우 난류유동(Turbulent flow)으로 가정 하였다. 난류유동의 경우 연속 방정식과 운동량 보존 방정식인 Reynolds-averaged Navier-Stokes(RANS) 방정식을 유동의 지배방 정식으로 사용하고, 난류모형으로 Realizable k- $\varepsilon$ 모형을 사용하 였다(Shin et al., 1995). 지배방정식의 해는 유한체적법(Finite volume method)으로 이산화 하였으며, 시간적분 및 공간에 대해 2 차 정도의 수치 이산화 기법이 사용되었다. 본 논문에서는 이러 한 수치해석 기법들을 이용 하는 상용프로그램 STAR-CCM+ (CD-adapco, 2015)를 이용하여 모든 수치해석을 수행하였다.

\section{2 자유수면 및 입사파 모델링}

수치해석을 통한 파 생성의 경우 자유수면의 운동학적 및 동 역학적 조건을 정확히 만족시키는 것이 중요하다. 본 논문에서 는 STAR-CCM+에 제공되는 2차 정확도의 VOF(Volume of fluid, Muzaferija and Perić, 1999)법을 사용하였다.

본 연구에서 입사파 진행 시뮬레이션의 수치 민감도 해석 및 $\mathrm{FPSO}$ 의 파랑중 운동해석에 필요한 수치파는 모형시험과 같은 조건으로 조파기를 직접적으로 모델링하는 방법이 아닌 파 이 론(Wave theory)에서 얻어진 파정보를 유동장 유입경계면에 입 력하는 방법을 사용하였다. 비선형파의 경우 Stokes $5^{\text {th }}$ 파 방정 식을 이용하였으며 파랑중 $\mathrm{FPSO}$ 운동 문제의 경우 작은 파기울 기를 고려할 때 선형파 방정식의 해를 이용하였다.

\section{3. 수치 해석 결과}

\subsection{2 차원 파 진행 문제 수치조건 민감도}

본 절에서는 주어진 조건의 비선형파를 정확히 시뮬레이션하 기 위해 필요한 격자수와 계산시간 간격 등의 수치해석 조건을 검토한 결과를 제공한다. 문제는 2 차원 문제로 취급하고 유동은 층류로 가정하였다. 여기서, 본 연구의 수치 계산 조건에 따른 수 치오차는 지배방정식의 이산화와 자유수면 처리 등의 적용된 수 치기법들의 오차를 같이 동반한 결과임을 고려하여 이해되어야 한다. 대상으로 하는 파는 파장 $(\lambda) 4 \mathrm{~m}$, 파고 $(H) 0.16 \mathrm{~m}$ 인 Stokes $5^{\text {th }}$ 파이다. 이 때, 유동장의 크기는 파장을 기준으로 파진행 방향 인 x 방향으로 $L_{x}=6.5 \lambda$, 높이 방향인 $\mathrm{z}$ 방향으로 $L_{z}=4.5 \lambda$, 그리 고 수심 $d=4.0 \lambda$ 이다. 여기서, 파의 감쇠를 유도하는 소파영역의 $\mathrm{x}$ 방향 길이는 유동장의 유출면을 기준으로 $x_{d}=2.5 \lambda$ 이다. 지배방 정식을 풀기 위한 수치해석 조건에서 하향완화계수(Under relaxation factor)의 경우 속도-압력 연성방정식은 0.5 를 사용하고, 그 외 운동량방정식과 자유수면 모델에 대한 변수들에 대해서는 0.9 를 사용했다. 총 시뮬레이션 시간은 파의 10 주기에 해당하는 16 초이다.

Table 1은 2차원 파 시뮬레이션을 통한 수치 민감도 분석을 위해 수행한 모든 해석 조건들을 나타내고 있다. 수치해석 조건 은 파장당 격자수 $\left(N_{x}\right)$, 파고당 격자수 $\left(N_{z}\right)$, 그리고 $\mathrm{CFL}$ (CourantFriedrichs-Lewy) 조건에 따른 계산시간 간격( $\Delta t)$ 그리고 전체 방정식들을 풀기위해 적용되는 내부 반복계산 횟수(Inner iteration)이며, 총 해석조건은 110 가지이다. 표에서는 파장 $4 \mathrm{~m}$, 파고 $0.16 \mathrm{~m}$ 의 파에 대한 격자수 및 단위 격자의 크기 $(\Delta x, \Delta z)$ 를 볼 수 있다. 격자수는 파장당 40 에서 160 개, 파고당 격자수

Table 1 Test cases for the propagation simulation of the given Stokes $5^{\text {th }}$ wave

\begin{tabular}{|c|c|c|c|c|c|}
\hline & $\begin{array}{l}\text { No. of } \\
\text { test cases }\end{array}$ & $\underset{\left(N_{x}\right)}{\triangle \mathrm{x}}$ & $\begin{array}{c}\triangle \mathrm{z} \\
\left(N_{z}\right)\end{array}$ & $\left(\mathrm{CFL}=0.1, \quad \triangle_{\mathrm{t}}\right.$ & $\begin{array}{l}\text { Inner } \\
\text { iteration }\end{array}$ \\
\hline 1 & 10 & $\begin{array}{l}0.1 \mathrm{~m} \\
(40 \text { cells })\end{array}$ & $\begin{array}{l}0.00625 \mathrm{~m} \\
(26 \text { cells })\end{array}$ & $\begin{array}{c}0.004 \mathrm{~s}(0.1), 0.008 \mathrm{~s}(0.2), 0.012 \mathrm{~s}(0.3) \\
0.016 \mathrm{~s}(0.4), 0.020 \mathrm{~s}(0.5)\end{array}$ & 5,10 \\
\hline 2 & 10 & $\begin{array}{l}0.07272 \mathrm{~m} \\
(55 \text { cells })\end{array}$ & $\begin{array}{l}0.004545 \mathrm{~m} \\
(35 \text { cells })\end{array}$ & $\begin{array}{c}0.00291 \mathrm{~s}(0.1), 0.00582 \mathrm{~s}(0.2), 0.00873 \mathrm{~s}(0.3) \\
0.01164 \mathrm{~s}(0.4), 0.01455 \mathrm{~s}(0.5)\end{array}$ & 5,10 \\
\hline 3 & 10 & $\begin{array}{l}0.05 \mathrm{~m} \\
(80 \text { cells })\end{array}$ & $\begin{array}{l}0.00625 \mathrm{~m} \\
(26 \text { cells })\end{array}$ & $\begin{array}{c}0.002 \mathrm{~s}(0.1), 0.004 \mathrm{~s}(0.2), 0.006 \mathrm{~s}(0.3) \\
0.008 \mathrm{~s}(0.4), 0.010 \mathrm{~s}(0.5)\end{array}$ & 5,10 \\
\hline 4 & 5 & $\begin{array}{l}0.0428 \mathrm{~m} \\
(94 \text { cells })\end{array}$ & $\begin{array}{l}0.0107 \mathrm{~m} \\
(15 \text { cells })\end{array}$ & $\begin{array}{c}0.001712 \mathrm{~s}(0.1), 0.003424 \mathrm{~s}(0.2), 0.005136 \mathrm{~s}(0.3) \\
0.006848 \mathrm{~s}(0.4), 0.008559 \mathrm{~s}(0.5)\end{array}$ & 10 \\
\hline 5 & 5 & $\begin{array}{l}0.0428 \mathrm{~m} \\
(94 \text { cells })\end{array}$ & $\begin{array}{l}0.00535 \mathrm{~m} \\
(30 \text { cells })\end{array}$ & $\begin{array}{c}0.001712 \mathrm{~s}(0.1), 0.003424 \mathrm{~s}(0.2), 0.005136 \mathrm{~s}(0.3) \\
0.006848 \mathrm{~s}(0.4), 0.008559 \mathrm{~s}(0.5)\end{array}$ & 10 \\
\hline 6 & 10 & $\begin{array}{c}0.04 \mathrm{~m} \\
(100 \text { cells })\end{array}$ & $\begin{array}{l}0.01 \mathrm{~m} \\
(16 \text { cells })\end{array}$ & $\begin{array}{c}0.0016 \mathrm{~s}(0.1), 0.0032 \mathrm{~s}(0.2), 0.0048 \mathrm{~s}(0.3) \\
0.0064 \mathrm{~s}(0.4), 0.0080 \mathrm{~s}(0.5)\end{array}$ & 5,10 \\
\hline 7 & 10 & $\begin{array}{l}0.04 \mathrm{~m} \\
(100 \text { cells })\end{array}$ & $\begin{array}{c}0.005 \mathrm{~m} \\
(32 \text { cells })\end{array}$ & $\begin{array}{c}0.0016 \mathrm{~s}(0.1), 0.0032 \mathrm{~s}(0.2), 0.0048 \mathrm{~s}(0.3) \\
0.0064 \mathrm{~s}(0.4), 0.0080 \mathrm{~s}(0.5)\end{array}$ & 5,10 \\
\hline 8 & 15 & $\begin{array}{l}0.0333 \mathrm{~m} \\
(120 \text { cells })\end{array}$ & $\begin{array}{l}0.00833 \mathrm{~m} \\
(19 \text { cells })\end{array}$ & $\begin{array}{c}0.001334 \mathrm{~s}(0.1), 0.002668 \mathrm{~s}(0.2), 0.004002 \mathrm{~s}(0.3) \\
0.005335 \mathrm{~s}(0.4), 0.008003 \mathrm{~s}(0.5)\end{array}$ & $5,10,20$ \\
\hline 9 & 15 & $\begin{array}{l}0.02858 \mathrm{~m} \\
(140 \text { cells })\end{array}$ & $\begin{array}{l}0.00714 \mathrm{~m} \\
(22 \text { cells })\end{array}$ & $\begin{array}{c}0.001144 \mathrm{~s}(0.1), 0.002287 \mathrm{~s}(0.2), 0.003431 \mathrm{~s}(0.3) \\
0.004574 \mathrm{~s}(0.4), 0.005718 \mathrm{~s}(0.5)\end{array}$ & $5,10,20$ \\
\hline 10 & 20 & $\begin{array}{l}0.025 \mathrm{~m} \\
(160 \text { cells })\end{array}$ & $\begin{array}{c}0.00625 \mathrm{~m} \\
(26 \text { cells })\end{array}$ & $\begin{array}{c}0.001 \mathrm{~s}(0.1), 0.002 \mathrm{~s}(0.2), 0.003 \mathrm{~s}(0.3) \\
0.004 \mathrm{~s}(0.4), 0.005 \mathrm{~s}(0.5)\end{array}$ & $\begin{array}{l}5,10,20, \\
30\end{array}$ \\
\hline
\end{tabular}


는 15 에서 35 개의 변화 범위를 가진다. 각각의 격자조건에 사용 한 계산시간 간격을 볼 수 있으며, 이 때 값들은 CFL값으로 표 현하여 $0.1,0.2,0.3,0.4$ 그리고 0.5 에 해당한다. 전체 방정식에 대한 내부 반복계산 횟수는 5 와 10 을 사용하고, 격자수가 많아 수렴이 더 필요할 것으로 판단되는 조건에서는 20 과 30 까지 사 용되었다.

수치해석 결과는 해당하는 파조건의 Stokes $5^{\text {th }}$ 파 이론해와 비 교하였다. 수치해석에서 파진폭에 대한 오차는 파정과 파저 별 도로 계산하였으며( $\triangle$ crest, $\triangle$ trough $)$, 유입 경계면 및 소파영역 에 인접한 파를 제외한 연속된 3 개의 파의 파정 및 파고에 대한

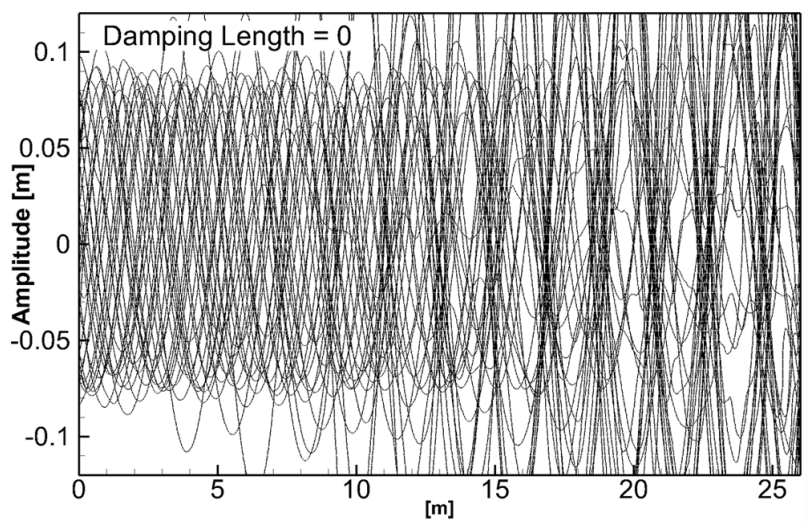

(a) Damping Length $=0$

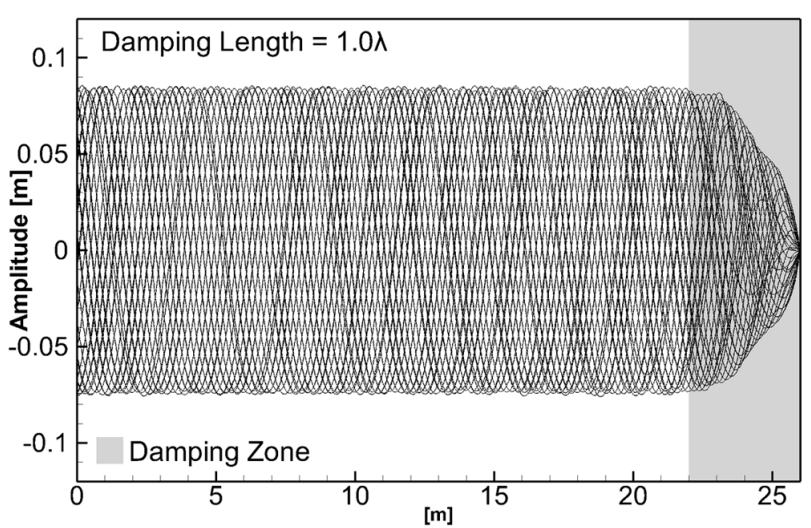

(c) Damping Length $=1.0 \lambda$

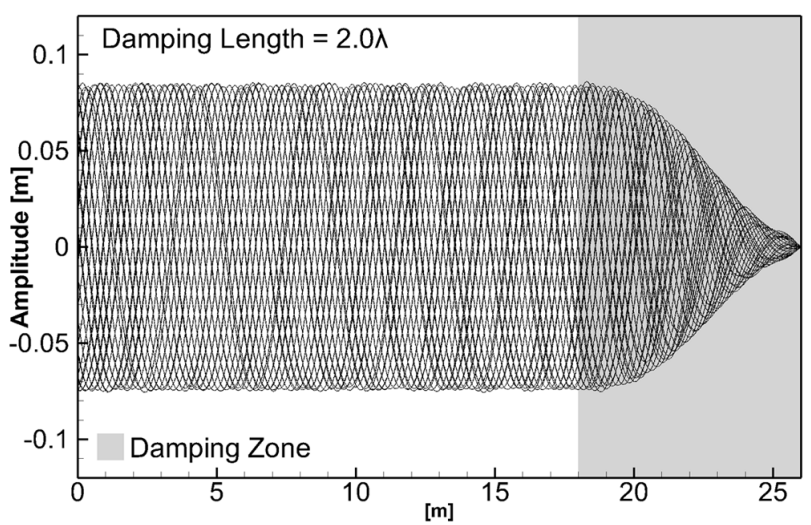

(e) Damping Length $=2.0 \lambda$
해석 해와의 차이에 대한 평균을 \%오차로 나타내었다. 파장의 오차는 유입 경계면에서 소파영역 시작점까지의 해석 해의 파 길이에 대한 수치해에서 얻은 파의 길이를 서로 비교하여 \%오 차( $\triangle$ phase $)$ 로 나타내었다.

파진행 시뮬레이션에서 중요한 수치 해석적 요소 중 하나로서 유동장 출구에서 파의 반사를 막아 반사파의 영향이 유동장 안으 로 들어오지 못하도록 하는 것이다. 본 연구에서는 STAR-CCM+ 에서 제공하는 소파영역내 파감쇠함수를 사용하여 파의 진폭을 감소시키는 방법을 사용하였다(Peric and Abdel-Maksoud, 2016).

Fig. 1은 소파영역의 크기에 따른 파의 반사 영향을 시간변화에

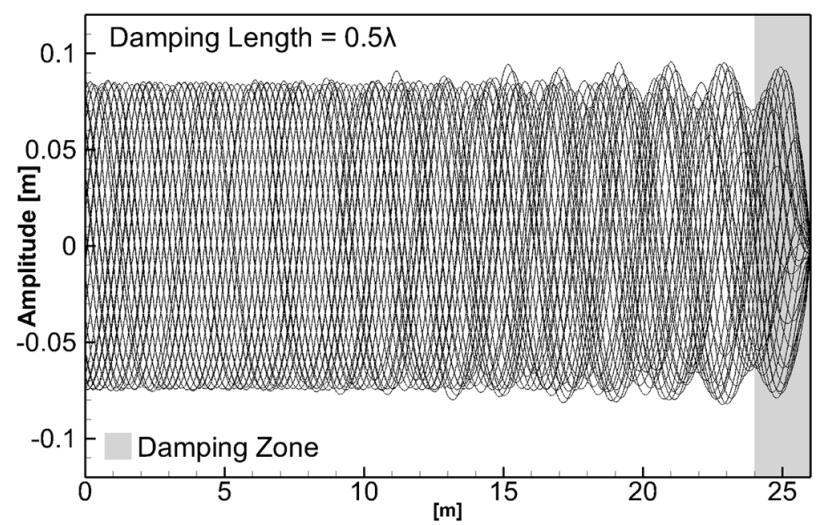

(b) Damping Length $=0.5 \lambda$

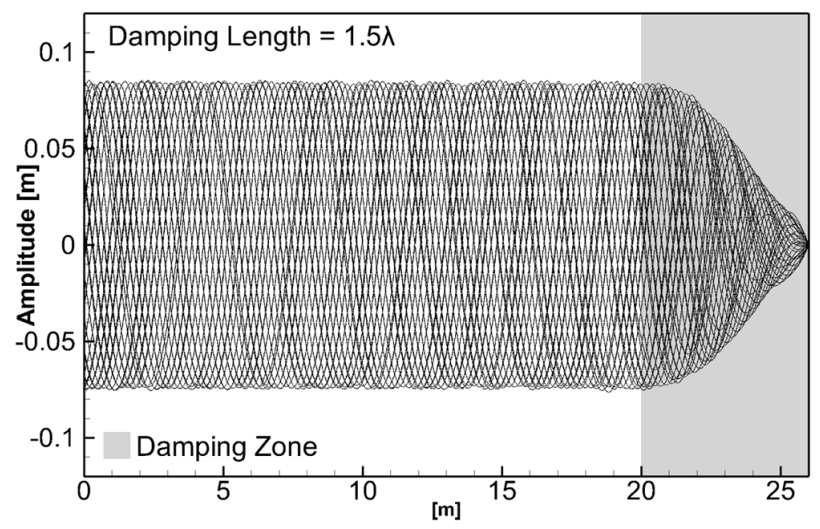

(d) Damping Length $=1.5 \lambda$

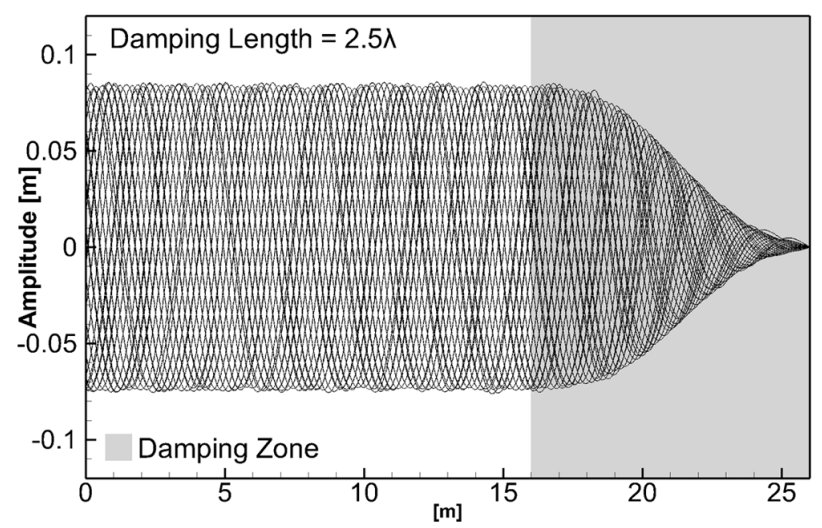

(f) Damping Length $=2.5 \lambda$

Fig. 1 Free surface elevation over x-location 


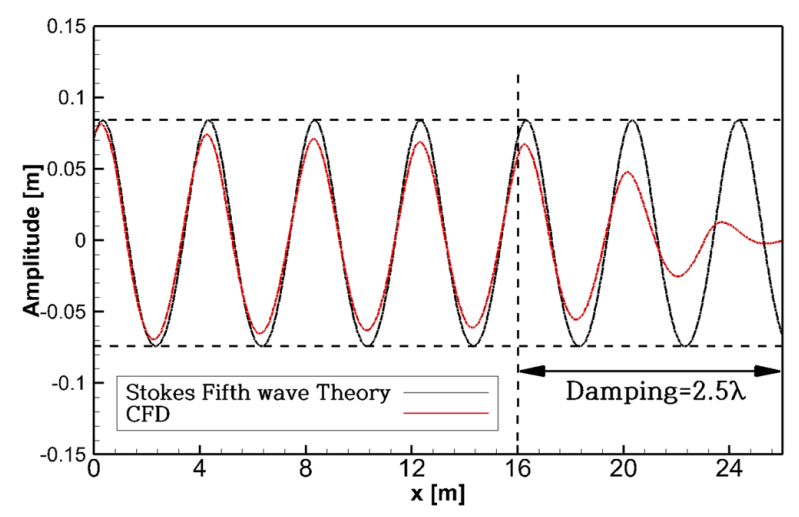

(a) $\Delta x=0.1 \mathrm{~m}$ (40 cells), $\Delta z=0.00625 \mathrm{~m}$ (26 cells), $\Delta t=0.008 \mathrm{~s}$

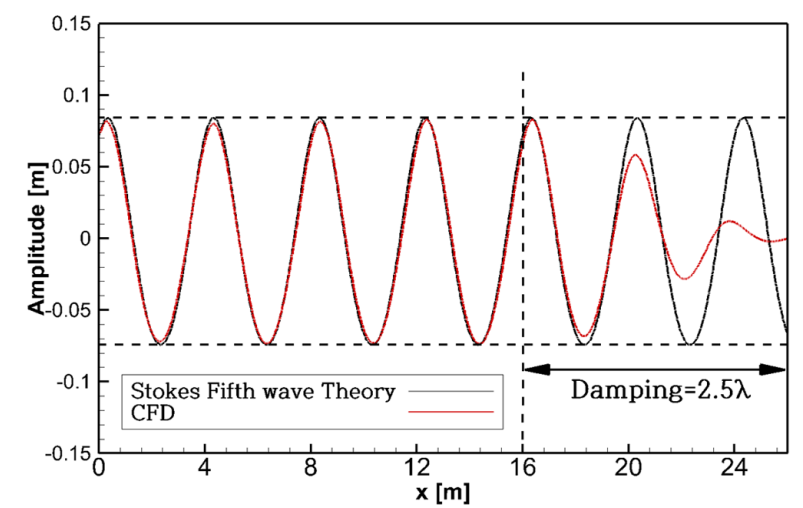

(b) $\Delta x=0.05 \mathrm{~m}(80$ cells $), \Delta z=0.00625 \mathrm{~m}(26$ cells $), \Delta t=0.004 \mathrm{~s}$

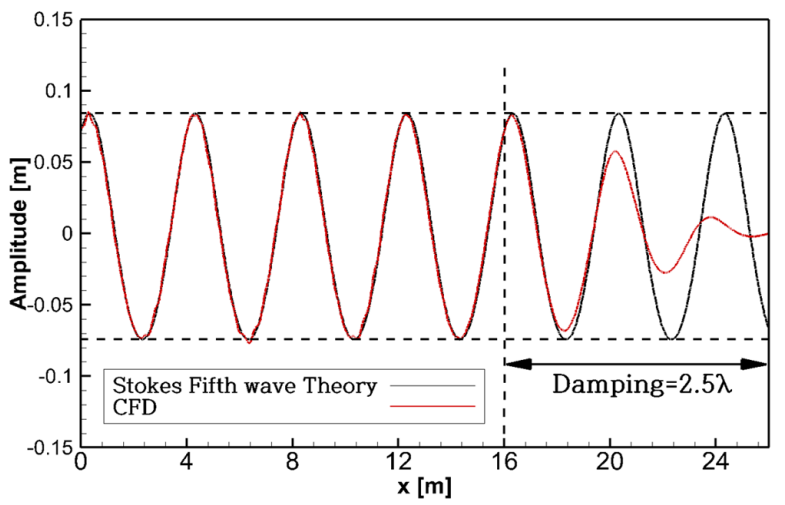

(c) $\Delta x=0.0428 \mathrm{~m}$ (94 cells), $\Delta z=0.0107 \mathrm{~m}$ (15 cells), $\Delta t=0.001712 \mathrm{~s}$

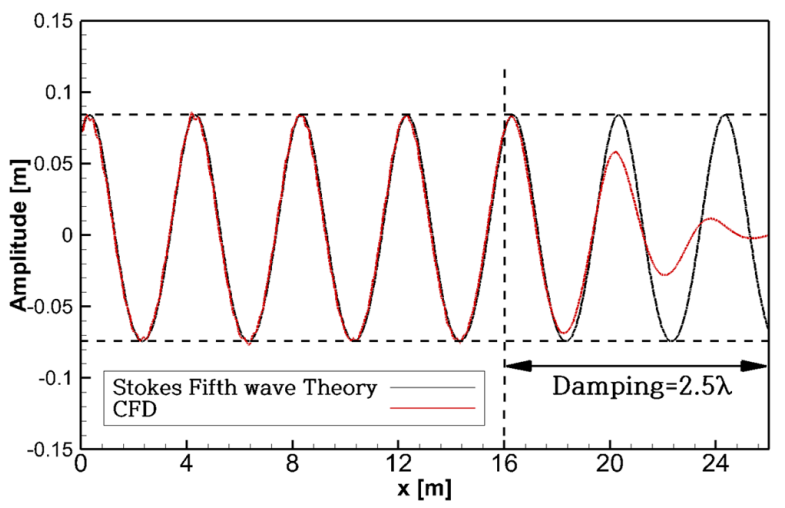

(d) $\Delta x=0.0333 \mathrm{~m}$ (120 cells), $\Delta z=0.0083 \mathrm{~m}$ (19 cells), $\Delta t=0.002668 \mathrm{~s}$

Fig. 2 Comparison of wave profiles; $\mathrm{CFL}=0.2$, inner iteration $=10$
따른 파형상을 비교하여 나타내고 있다. 최종적으로 본 논문에서 는 소파영역을 유동장 출구에서 상류 방향으로 파장의 2.5 배로 설 정하였다. 이 값의 타당성은 Peric and Abdel-Maksoud(2016)의 결 과에서도 동일하게 소개하고 있으며, 소파영역이 파장의 1 배 이상 일 때 유출 경계면에서 반사율이 많이 감소하는 것을 알 수 있다. 본 수치해석에서 사용된 파장당 격자수 $N_{x}=100$ 개, 파고당 격자 수 $N_{z}=32$ 개 그리고 CFL조건으로 0.2 의 값을 사용하였다.

Fig. 2는 CFL 0.2, Inner iteration=10의 조건에서 파장당 격자 수의 증가에 따른 10 주기 시간인 $16 \mathrm{~s}$ 때 해석 공간상에서 수치 해와 해석해의 파형을 비교하고 있다. 계산 시간 간격이 작은, 낮은 $\mathrm{CFL}$ 조건임에도 파장당 격자수 40 의 결과는 해석해와 진 폭과 파장의 차이를 보이고 파장당 격자수가 80 개 이후 해석해 와 비교적 좋은 일치를 보여주고 있다. 다만, 파장당 격자수 120 개 이상의 경우 파 표면에 불규칙한 수치적 Wiggle(Irregular point to point oscillation)현상이 발생하였다. 이 현상은, 우선은 수렴문제로 판단되며 수렴을 위해 더 많은 Inner iteration이 필 요한 것으로 사료된다.

Fig. 3은 Inner iteration에 따른 해의 수렴 정도를 비교하고 있 다. 파장당 격자수 80 개와 파고당 격자수 26 개 그리고 $\mathrm{CFL}$ 조 건 0.3 에서 Inner iteration 5 와 10 의 결과를 비교하고 있다. Inner iteration의 증가로 파형의 진폭 및 파장의 정도가 해석해와 비교 해 높아진 것을 볼 수 있다.

Fig. 4는 주어진 파장당 격자수와 파고당 격자수 조건에서 $\mathrm{CFL}$ 값을 변화시켜 얻어진 수치해들을 파정과 파저에서의 파

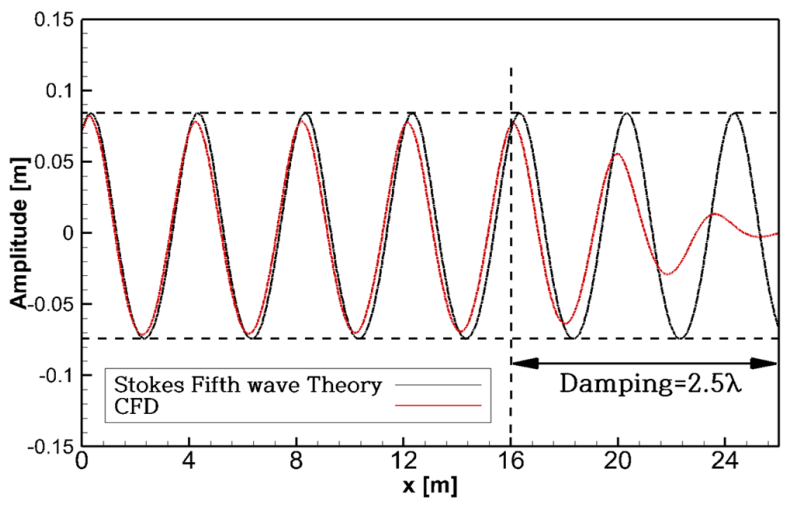

(a) Inner iteration $=5$

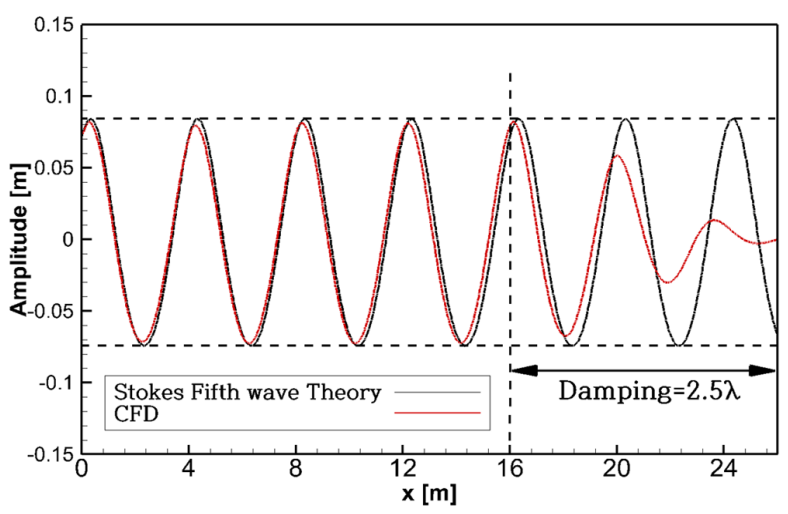

(b) Inner iteration $=10$

Fig. 3 Effect of inner iteration; $N_{x}=80, N_{z}=26, \mathrm{CFL}=0.3$ 


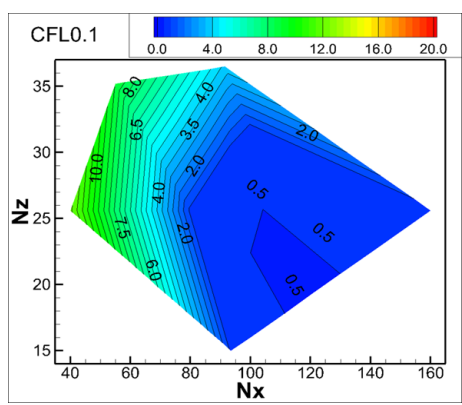

(a) $\triangle$ crest ; $\mathrm{CFL}=0.1$

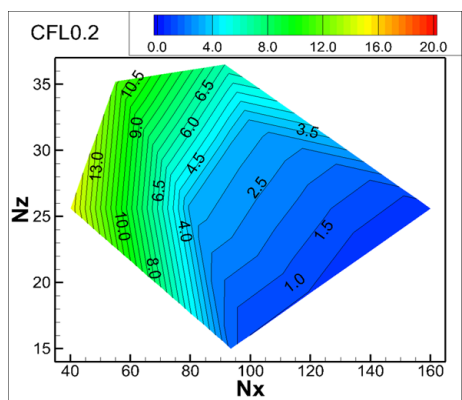

(d) $\triangle$ crest ; $\mathrm{CFL}=0.2$

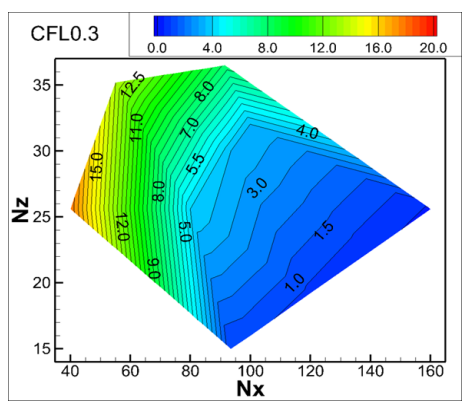

(g) $\Delta$ crest ; $\mathrm{CFL}=0.3$

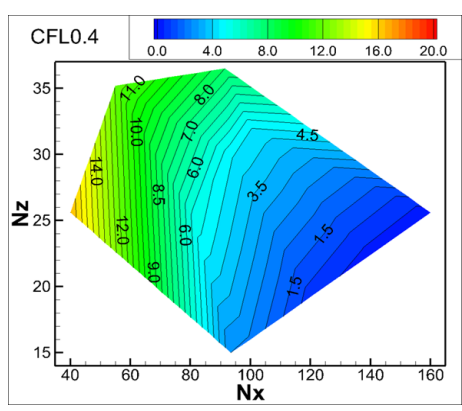

(j) $\triangle$ crest ; CFL $=0.4$

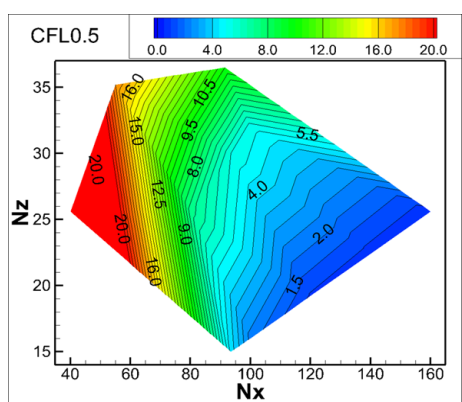

(m) $\triangle$ crest ; $\mathrm{CFL}=0.5$

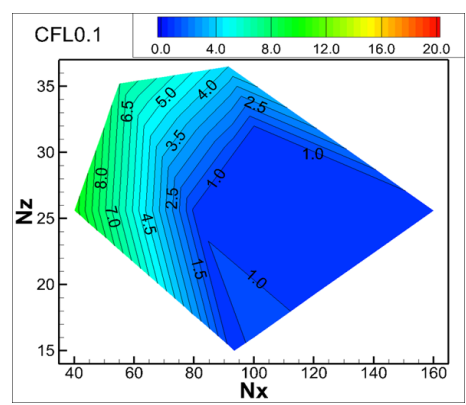

(b) $\triangle$ trough ; CFL $=0.1$

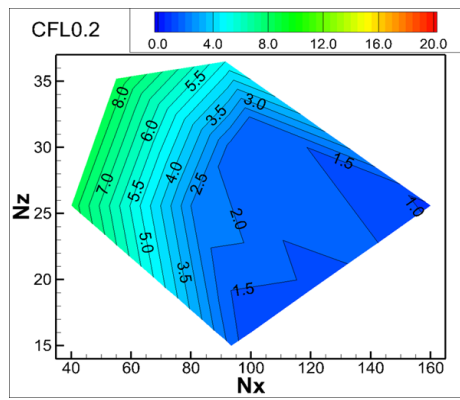

(e) $\triangle$ trough ; CFL $=0.2$

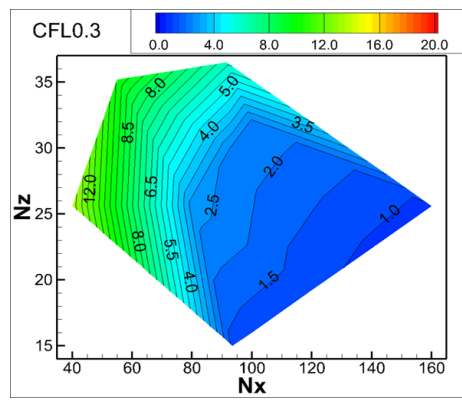

(h) $\triangle$ trough; CFL $=0.3$

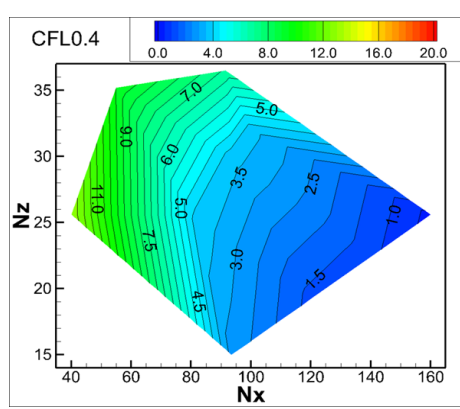

(k) $\triangle$ trough ; CFL $=0.4$

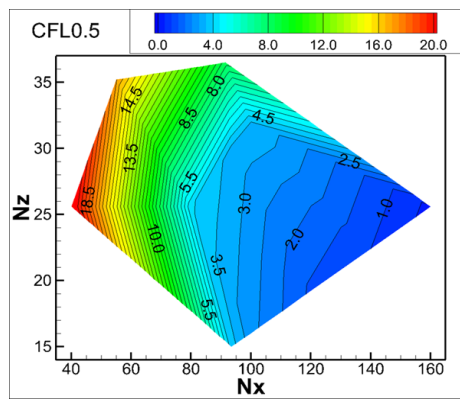

(n) $\triangle$ trough; $\mathrm{CFL}=0.5$

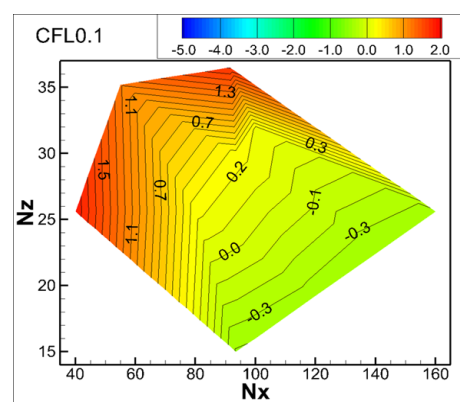

(c) $\triangle$ phase ; $\mathrm{CFL}=0.1$

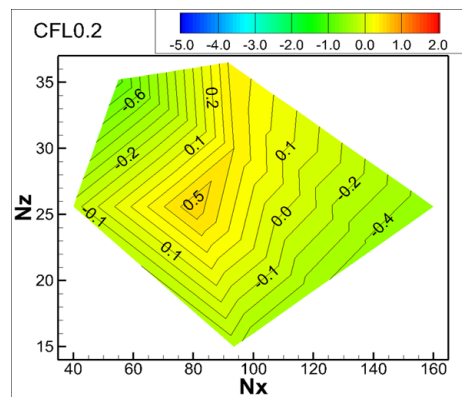

(f) $\triangle$ phase ; $\mathrm{CFL}=0.2$

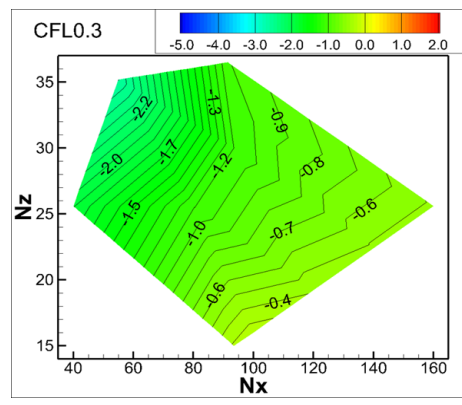

(i) $\triangle$ phase ; $\mathrm{CFL}=0.3$

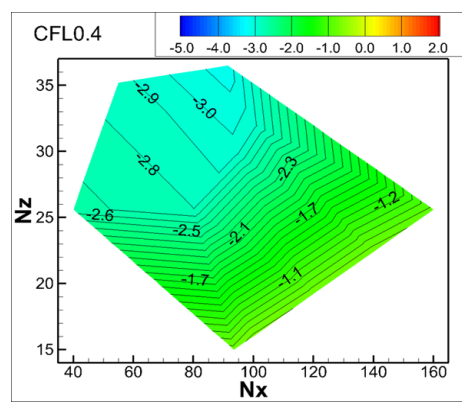

(l) $\triangle$ phase ; $\mathrm{CFL}=0.4$

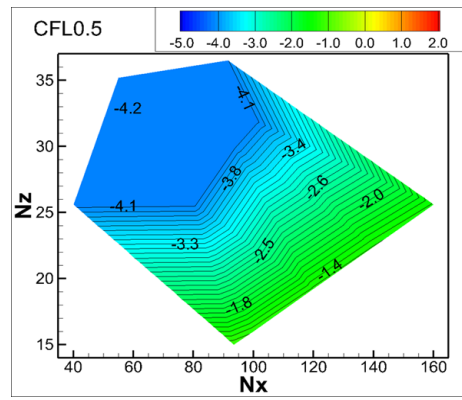

(o) $\triangle$ phase ; $\mathrm{CFL}=0.5$

Fig. 4 Error distributions of wave amplitude and wave length 
진폭 오차와 파장에 대한 위상오차를 CFL조건에 따라 \%오차 분포도를 작성한 결과를 보여주고 있다. 이 분포도를 통해 격자 수 및 CFL조건에 따른 수치해의 민감도를 파악할 수 있도록 하 였다.

Table 2 Additional test cases for the validation of wave propagation simulation

\begin{tabular}{cccc}
\hline \hline Test case & $\lambda$ & $H$ & Wave steepness \\
\hline 1 & 2.00 & 0.100 & 0.0500 \\
2 & 3.62 & 0.200 & 0.0550 \\
3 & 6.10 & 0.304 & 0.0498 \\
\hline
\end{tabular}

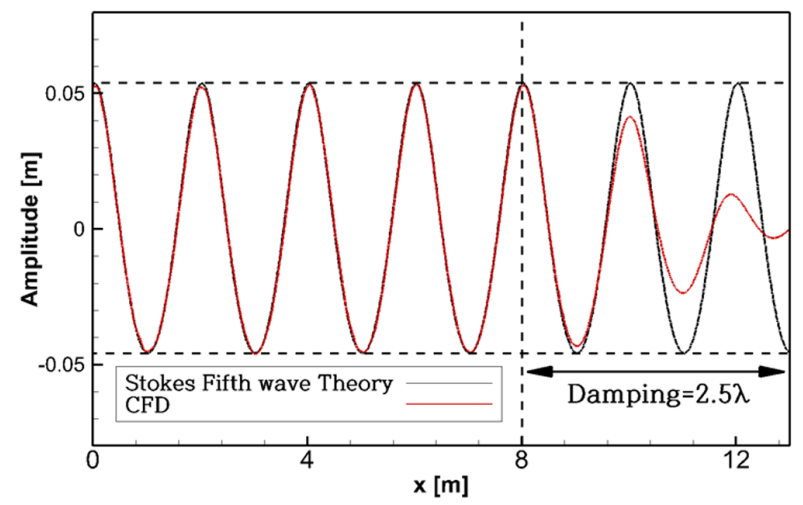

(a) $\lambda=2 \mathrm{~m} \& H=0.1 \mathrm{~m}$

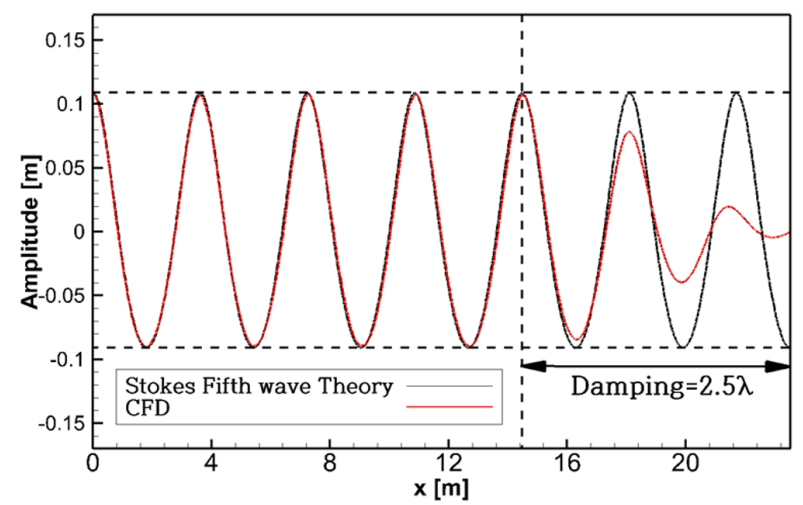

(b) $\lambda=3.62 \mathrm{~m} \mathrm{\&} H=0.2 \mathrm{~m}$

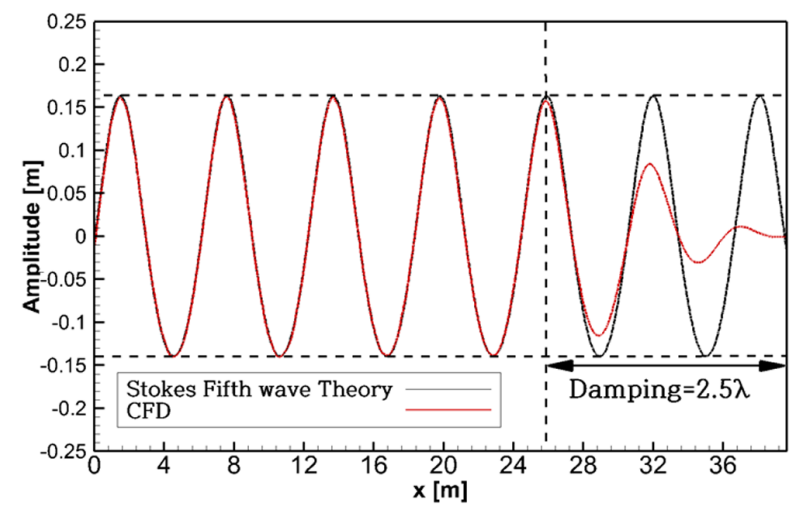

(c) $\lambda=6.1 \mathrm{~m} \mathrm{\&} H=0.304 \mathrm{~m}$

Fig. 5 Comparison of wave profiles for different wave conditions

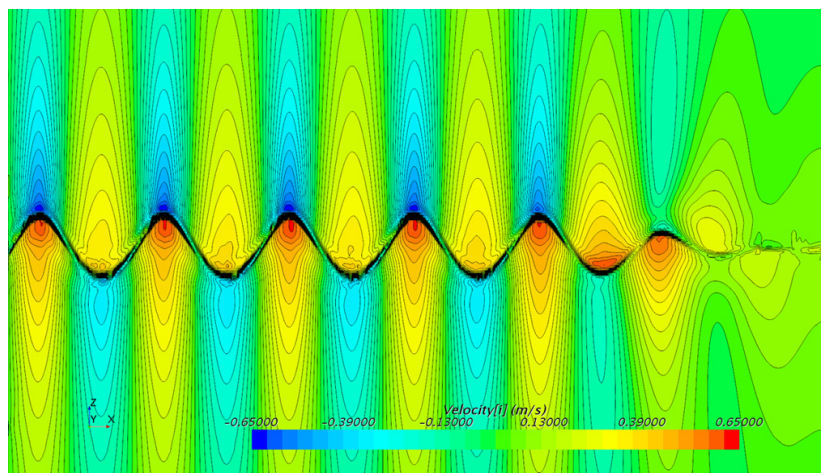

(a) velocity $X$

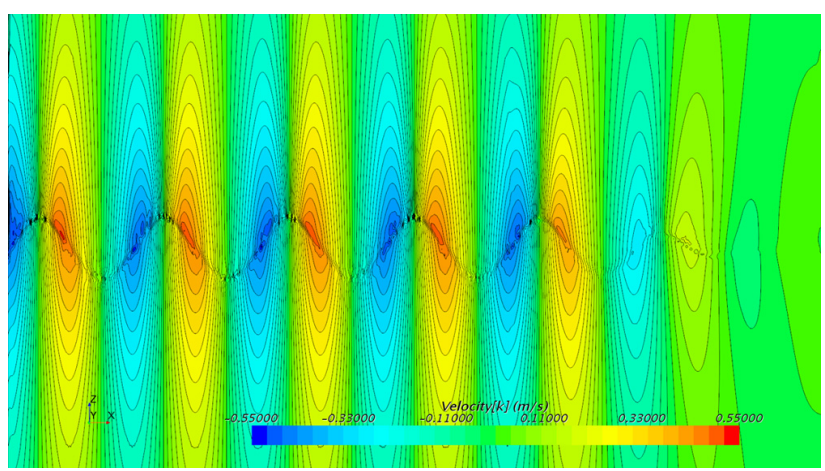

(b) velocity $Z$

Fig. 6 Fluid velocities computed for the wave of $\lambda=6.1 \mathrm{~m} \& H$ $=0.304 \mathrm{~m}$

CFL 0.1에서 0.5 의 각각의 오차 분포도를 살펴볼 때 파장과 파고당 격자수에 대한 해의 정확도 분포가 선형적인 특성이 아 닌 것을 볼 수 있다.

Table 2는 Fig. 4의 오차 분포도 결과를 대상 조건의 파가 아 닌 다른 파 조건들에 적용하고 검증을 수행한 세 가지 파를 설 명하고 있다. 여기서, 오차는 $2 \%$ 내외가 될 수 있는 범위의 격자 수를 선택하고 CFL 0.2 조건을 선택하였다.

Fig. 5는 각각 파장 $2 \mathrm{~m}$, 파고 $0.1 \mathrm{~m}$ 파, 파장 $3.62 \mathrm{~m}$, 파고 $0.2 \mathrm{~m}$ 파 그리고 파장 $6.1 \mathrm{~m}$, 파고 $0.304 \mathrm{~m}$ 파에 대한 10 주기 시뮬레이 션 이후 파형을 해석해와 비교하고 있다. 파장 $2 \mathrm{~m}$, 파고 $0.1 \mathrm{~m}$ 파의 경우 파 기울기는 0.05 이고 파장당 격자수는 125 개, 파고 당 격자수는 25 개이다. 파장 $3.62 \mathrm{~m}$, 파고 $0.2 \mathrm{~m}$ 파의 경우 파 기 울기가 0.055 이고 파장당 격자수 113 개, 파고당 격자수 25 개이 며, 파장 $6.1 \mathrm{~m}$, 파고 $0.304 \mathrm{~m}$ 파의 경우 파 기울기는 0.0498 , 파장 당 격자수 118 개 그리고 파고당 격자수는 24 개로 구성되어 있 다. 결론적으로, Fig. 4의 분포도를 활용하여 격자를 결정한 세 가지 해석의 결과에서 파정과 파저에서의 진폭 및 파장에 대한 위상차이가 매우 작은 양상으로 Stokes $5^{\text {th }}$ 해석해와 좋은 일치 를 보이고 있다.

Fig. 6은 파장 $6.1 \mathrm{~m}$, 파고 $0.304 \mathrm{~m}$ 파 주위 유동장에서의 잘 수 렴된 $\mathrm{x}$ 축 방향 및 $\mathrm{z}$ 축 방향 유체의 속도분포를 보여주고 있다.

\section{2 파랑중 FPSO 운동 해석 수치격자 민감도}

본 절에서는 앞선 2 차원 파 시률레이션을 통한 수치 해석조 건 민감도 분석 결과를 바탕으로 파랑중 FPSO 운동 시뮬레이션 


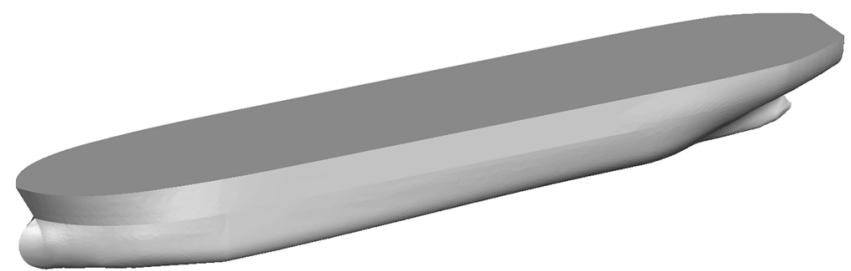

Fig. 7 Hull form of KRISO FPSO

Table 3 Main dimensions of KRISO FPSO

\begin{tabular}{cccc}
\hline \hline \multirow{2}{*}{ Item } & Unit & \multicolumn{2}{c}{ Full load 140 K (1/60) } \\
& & Ship & Model \\
\hline Length, Lpp & $\mathrm{m}$ & 239.0 & 3.983 \\
Breadth, B & $\mathrm{m}$ & 45.82 & 0.764 \\
Draft(FP) & $\mathrm{m}$ & 15.82 & 0.264 \\
Draft(Mid) & $\mathrm{m}$ & 15.82 & 0.264 \\
Draft(AP) & $\mathrm{m}$ & 15.82 & 0.264 \\
Displacement & $\mathrm{m}^{3}$ & 139,585 & 0.6462 \\
LCG & $\mathrm{m}$ & +9.636 & 0.1606 \\
GM & $\mathrm{m}$ & 6.028 & 0.0838 \\
KG & $\mathrm{m}$ & 14.54 & 0.2423 \\
Kyy $=$ Kzz & $\mathrm{m}$ & 59.75 & 0.996 \\
Kxx & $\mathrm{m}$ & 16.04 & 0.267 \\
\hline
\end{tabular}

의 수치격자 민감도 검토 결과를 제공한다. Fig. 7은 해석의 대 상이 되는 FPSO 선형의 모습을 보여주고 있다. Table 3에서 길 이 $239 \mathrm{~m}$ 인 $\mathrm{FPSO}$ 선형의 주요제원을 나타내고 있다. 선폭은 $45.82 \mathrm{~m}$ 이고 흘수가 $15.82 \mathrm{~m}$ 그리고 운동해석에 필요한 회전반경 및 중심의 위치를 확인할 수 있다. 수치해석은 축척비 $1 / 60$ 인 $3.983 \mathrm{~m}$ 의 모형선에 대해 수행하였다.

Table 4는 수치해석에서 사용한 FPSO로 유입되는 파 조건으 로서 실선을 기준으로 하였을 때 $0.4,0.5,0.6,0.7$ 파진동수에 해당하는 선수 규칙파의 파고, 파주기 그리고 파장을 모형선시 험 조건과 비교하고 있다. 여기서, 선체의 위치 유지를 위해 계 류선이 사용되고 본 수치해석은 스프링 모델로 이를 재현하였 다(Hong et al. 2002). 참고로 모형선의 길이가 약 $4 \mathrm{~m}$ 일 때, 0.4 는 파장이 $7.6 \mathrm{~m}, 0.5$ 는 $4.1 \mathrm{~m}, 0.6$ 은 $2.9 \mathrm{~m}, 0.7$ 은 약 $2.1 \mathrm{~m}$ 이다. 파 고는 $0.033 \mathrm{~m}$ 이다. 이 때 각 파진동수에 해당하는 파기울기들은 앞서 수치 해석조건 민감도 분석을 위해 수행한 2 차원 문제의

Table 4 Wave conditions for the numerical simulations

\begin{tabular}{cccc}
\hline \hline $\begin{array}{c}\text { Freq. } \\
{[\mathrm{rad} / \mathrm{s}]}\end{array}$ & $\begin{array}{c}\text { Wave Height }[\mathrm{m}] \\
{[\text { proto/model] }} \\
(* \text { Wave steepness })\end{array}$ & $\begin{array}{c}\text { Wave Period } \\
{[\mathrm{s}]}\end{array}$ & $\begin{array}{c}\text { Wave length } \\
{[\mathrm{m} \text { [ }]}\end{array}$ \\
\hline 0.4 & $2 / 0.033\left({ }^{*} 0.00437\right)$ & $15.71 / 2.028$ & $453.4 / 7.556$ \\
0.5 & $2 / 0.033\left({ }^{*} 0.00804\right)$ & $12.56 / 1.622$ & $246.4 / 4.106$ \\
& $2 / 0.033\left({ }^{*} 0.01157\right)$ & $10.47 / 1.352$ & $171.2 / 2.853$ \\
0.6 & $3 / 0.050\left({ }^{*} 0.01753\right)$ & $10.47 / 1.352$ & $171.2 / 2.853$ \\
& $4 / 0.067\left({ }^{*} 0.02348\right)$ & $10.47 / 1.352$ & $171.2 / 2.853$ \\
0.7 & $2 / 0.033\left({ }^{*} 0.01574\right)$ & $8.98 / 1.159$ & $125.8 / 2.096$ \\
\hline
\end{tabular}

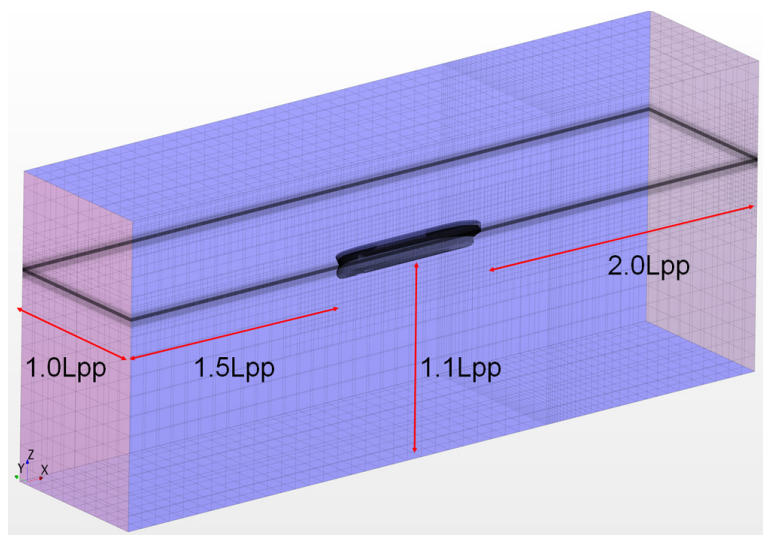

Fig. 8 Size of flow domain

파들 보다 작은 조건이다. 파 진동수 0.6 의 경우 파고 변화에 따 른 해의 변화를 살펴보기 위해 파고 $0.05 \mathrm{~m}$ 와 $0.067 \mathrm{~m}$ 의 두 가지 계산 조건을 추가되었다.

Fig. 8은 FPSO 선체를 중심으로 유동장의 크기를 설명하고 있다. 유동장에 파가 입사되는 유입경계면은 상류쪽으로 $1.5 \mathrm{Lpp}$ 에 위치해있으며, 유출경계면은 하류 $2.0 \mathrm{Lpp}$ 의 거리에 떨어져 있다. 선체의 측면으로는 $1.0 \mathrm{Lpp}$, 깊이방향으로는 $1.1 \mathrm{Lpp}$ 의 크기 를 가진다.

파랑중 FPSO 운동해석에서는 유동장 경계에서 파의 수치적 반사현상을 막기 위해 STAR-CCM+에 프로그램 되어있는 다른 소파방법을 활용하였다. 앞서 2차원 연구에서 입사파의 파장의 2.5 배의 소파영역을 두는 방법과는 달리, 경계면 부근에서 유동 장 내부의 파와 주어진 입사파가 일정 영역에서 수학적으로 조 화시켜 반사파를 강제하는 일명 Wave forcing법을 사용하였다. 본 방법을 이용한 2차원 진행파 검증은 Enger et al.(2014)의 연 구결과를 참조할 수 있다. 이 방법은 앞선 방법보다 Forcing영역 을 짧게 할 수 있어 격자의 수를 줄일 수 있다. Forcing영역의 크기는 유입경계면에서 $0.9 \mathrm{Lpp}$, 유출경계면에서 $0.5 \mathrm{Lpp}$, 측면에 서 $0.25 \mathrm{Lpp}$ 의 크기를 가지도록 설정하였다.

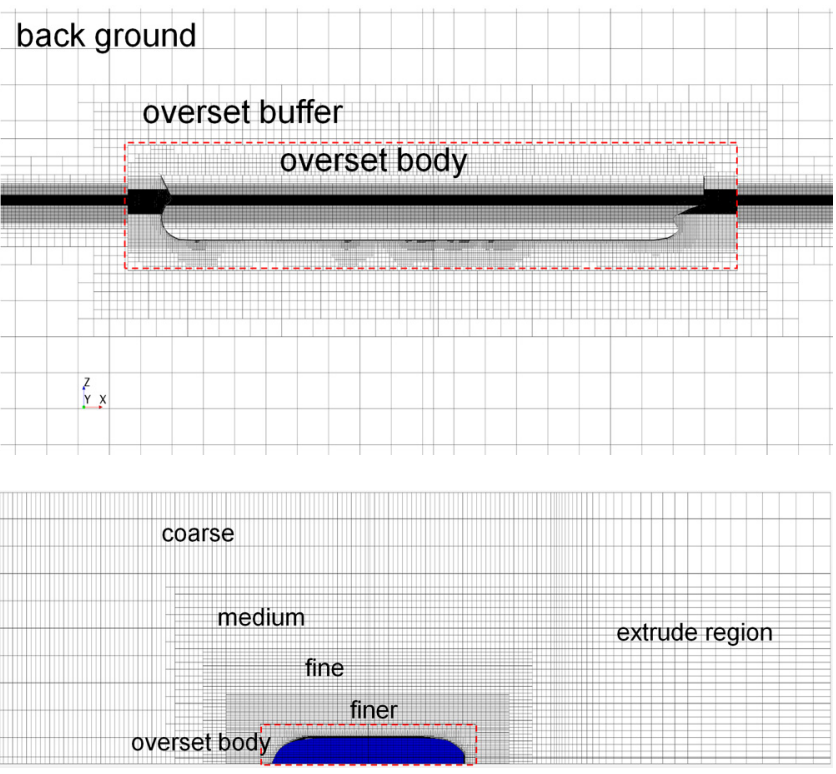

Fig. 9 Strategy of grid generation 


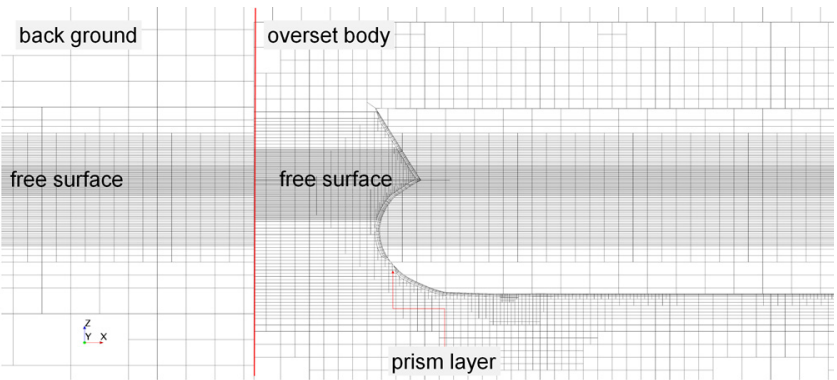

Fig. 10 Overset grid distribution around the hull

Table 5 Grid conditions for each wave condition

\begin{tabular}{|c|c|c|c|c|c|}
\hline \multicolumn{4}{|c|}{ Grid size } & \multirow{2}{*}{$\begin{array}{l}\text { Total No. of } \\
\text { grids }\end{array}$} & \multirow{2}{*}{$\begin{array}{c}\Delta t \\
(\mathrm{CFL}=0.3 \text {, inner } \\
\text { iteration }=7)\end{array}$} \\
\hline$w$ & $N_{x}$ & $N_{z}$ & & & \\
\hline \multirow{3}{*}{0.4} & 100 & 14 & Grid 1 & $1.69 \mathrm{M}$ & 0.0066 \\
\hline & 129 & 18 & Grid 2 & $2.95 \mathrm{M}$ & 0.0050 \\
\hline & 172 & 24 & Grid 3 & $5.58 \mathrm{M}$ & 0.0038 \\
\hline \multirow{3}{*}{0.5} & 109 & 14 & Grid 1 & $2.08 \mathrm{M}$ & 0.0045 \\
\hline & 137 & 18 & Grid 2 & $3.58 \mathrm{M}$ & 0.0036 \\
\hline & 179 & 23 & Grid 3 & $6.48 \mathrm{M}$ & 0.0028 \\
\hline \multirow{3}{*}{0.6} & 81 & 15 & Grid 1 & $2.70 \mathrm{M}$ & 0.0048 \\
\hline & 102 & 19 & Grid 2 & $4.37 \mathrm{M}$ & 0.0040 \\
\hline & 124 & 23 & Grid 3 & $6.50 \mathrm{M}$ & 0.0033 \\
\hline \multirow{3}{*}{0.7} & 71 & 18 & Grid 1 & $3.88 \mathrm{M}$ & 0.0040 \\
\hline & 83 & 21 & Grid 2 & $5.30 \mathrm{M}$ & 0.0036 \\
\hline & 95 & 24 & Grid 3 & $7.52 \mathrm{M}$ & 0.0030 \\
\hline
\end{tabular}

Fig. 9는 선체 주위 격자 분포 모습을 보여주고 있다. 수치격 자는 크게 배경격자와 운동을 하는 내부격자 그리고 두 격자간 내삽(Interpolation)이 이루어지는 완충(Buffer)영역으로 나누었다. 자유수면에 대한 격자 조밀도는 그림과 같이 여러 영역으로 나 누어 조정하였다.

Fig. 10은 선체 주위 배경격자 및 선체를 포함하는 운동 격자 내 자유수면 영역의 격자 분포 상황을 보여주고 있다.

Table 5 는 2 차원 문제를 통해 검토한 수치 민감도 분석 결과 를 바탕으로 결정된 파랑중 $\mathrm{FPSO}$ 운동 해석에 사용된 격자 조건 들을 나타내고 있다. 각각의 파 진동수 조건에 대해 세 가지 격 자를 생성하였다. 이는 전체 격자수가 작은 경우 해석시간을 줄 일 수 있지만 해의 정도를 검토하고자 하였다. 파장당 격자수는 71 에서 179 까지 그리고 파고당 격자수는 14 에서 24 까지 사용되 었다. 전체 격자수는 대략 작은 경우 1 백6십만개에서 3 백9십만 개, 중간크기는 2 백9십만개에서 5 백 3 십만개, 가장 조밀한 경우 5 백5십만개에서 7 백5십만개이다. 전체 격자수는 파진동수가 클 때 파장당 격자수가 작아도 크게 증가하는 것을 볼 수 있다.

CFL조건은 0.3, Inner iteration은 7로 설정하여 계산을 수행하 였다. Table에서 각 격자에 대해 CFL 0.3 에 해당하는 계산시간 간격을 볼 수 있다.

Figs. 11-14은 파 진동수 $0.4,0.5,0.6$ 그리고 0.7에서 FPSO의 운동응답을 격자 조건에 대해 비교하고 있다. Fig. 11는 파 진동 수 0.4의 선수파 조건에서 계산된 시간에 따른 상하동요(Heave), 종동요(Pitch) 그리고 전진동요(Surge) 운동의 시간에 따른 진폭 변화를 보여주고 있다. 각 조건에서 약 20 초 이후 운동들이 수

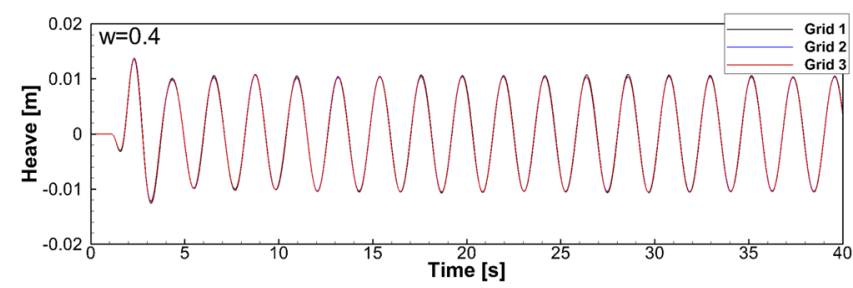

(a) Heave motion

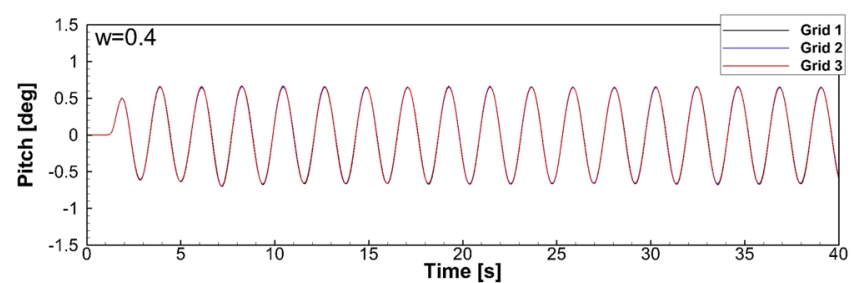

(b) Pitch motion

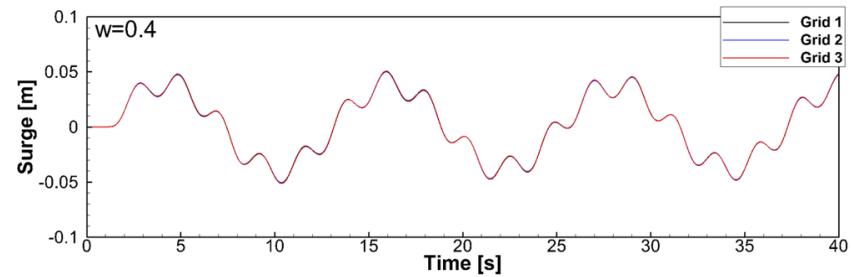

(c) Surge motion

Fig. 11 Motion results at $\omega=0.4$

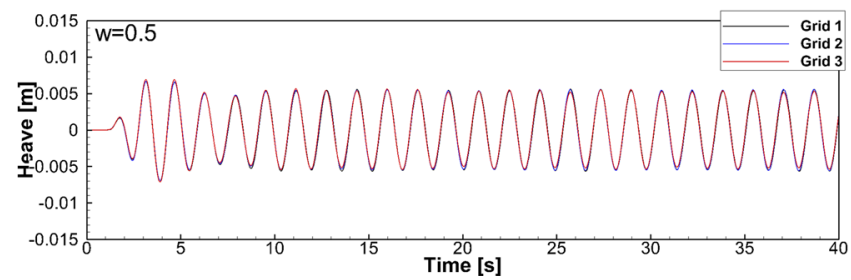

(a) Heave motion

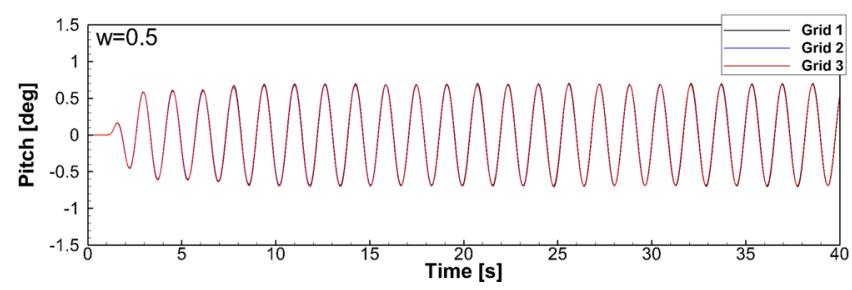

(b) Pitch motion

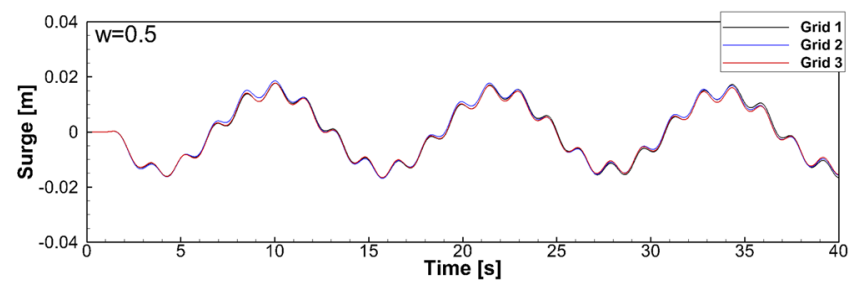

(c) Surge motion

Fig. 12 Motion results at $\omega=0.5$

렴하고 있으며, 세 가지 격자 조건에서 계산된 결과들은 서로 잘 일치하는 것을 볼 수 있다. 유동의 선형성(Linearity)이 지배 
적인 낮은 파 진동수 조건에서는 격자간 해의 차이는 크지 않 은 것을 볼 수 있다.

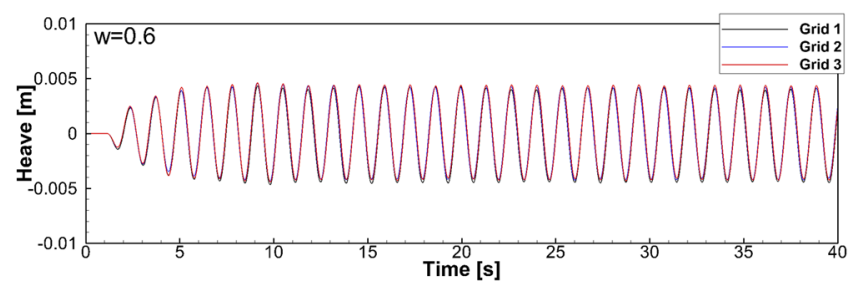

(a) Heave motion

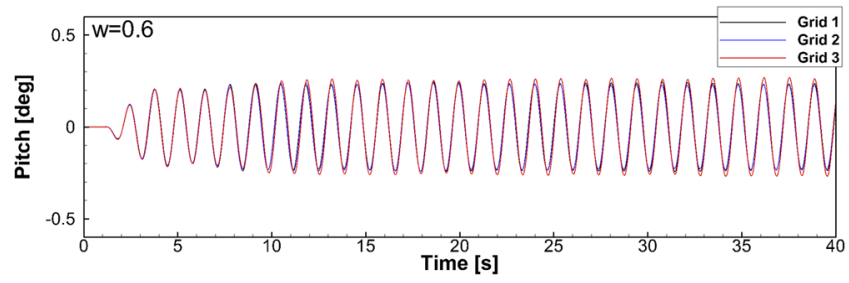

(b) Pitch motion

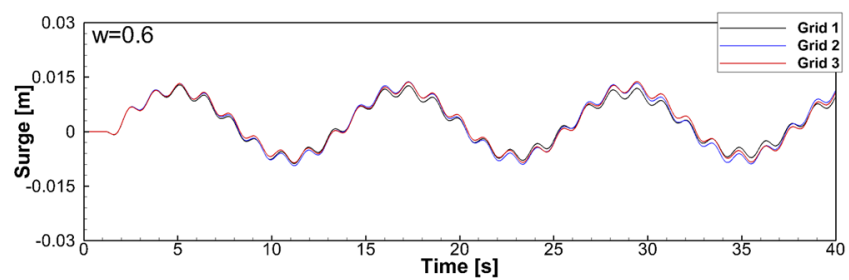

(c) Surge motion

Fig. 13 Motion results at $\omega=0.6$

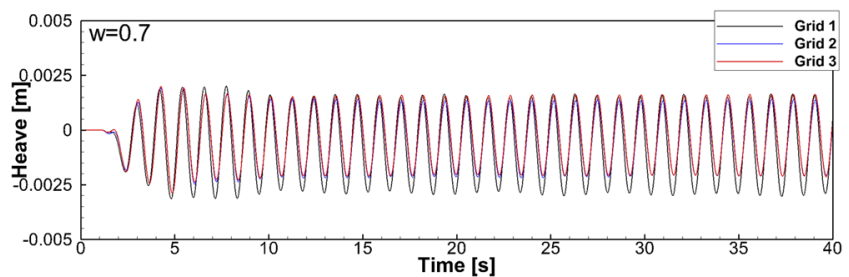

(a) Heave motion

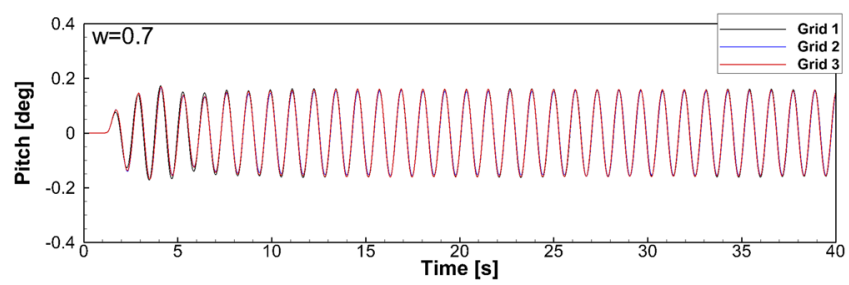

(b) Pitch motion

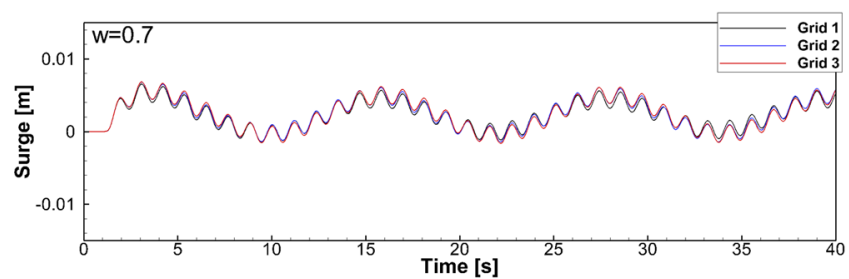

(c) Surge motion

Fig. 14 Motion results at $\omega=0.7$

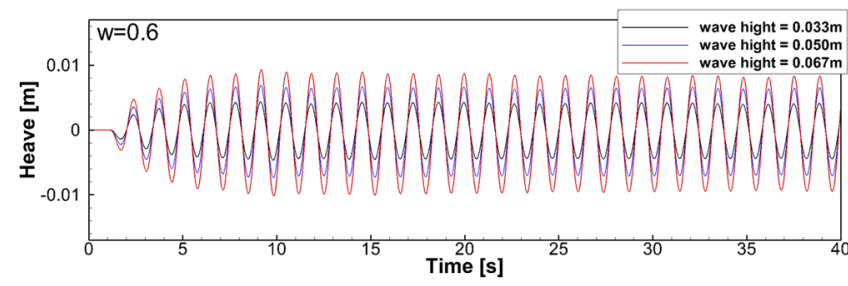

(a) Heave motion

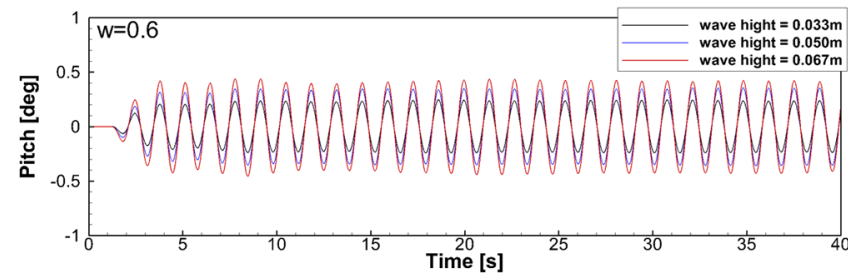

(b) Pitch motion

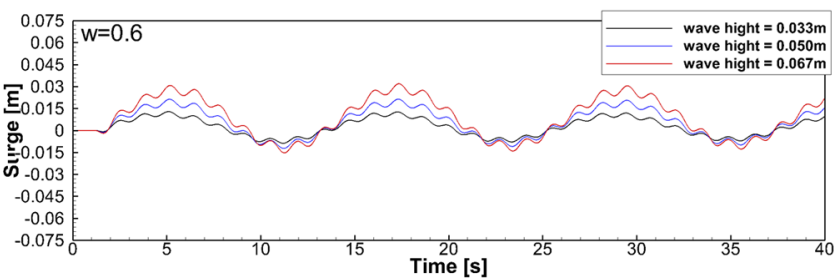

(c) Surge motion

Fig. 15 Motion results varying wave height at $\omega=0.6$

Fig. 12 은 파 진동수 0.5 의 결과를 비교하고 있다. 파 진동수 0.4 의 결과와 마찬가지로, 본 조건의 경우에도 세 가지 격자에 서 얻어진 결과들이 서로 잘 일치하는 것을 볼 수 있다.

Fig. 13 과 14 는 파 진동수 0.6 과 0.7 운동의 시간에 따른 진폭변 화를 각각 비교하고 있다. 파의 기울기와 비선형 특성이 커지면서 격자 간 운동진폭의 차이가 약간 나타나는 것을 볼 수 있다. 파 진동수 0.7 의 경우 가장 작은 격자수의 상하동요 운동진폭이 다른 격자들과는 조금 더 차이를 보이고 있다. 그러나 이러한 차이는 다음에 비교하게 될 운동의 RAO(Response amplitude operator) 관 점에서는 큰 차이가 아닌 것으로 판단된다. 그 외 다른 운동의 진 폭들의 차이는 앞선 파 진동수 0.4 와 0.5 보다는 크지만 비교적 서 로 일치하는 것을 볼 수 있다.

Fig. 15 는 파 진동수 0.6 에 대해 파고의 변화에 따른 $\mathrm{FPSO}$ 의 상하동요, 종동요 및 전진동요 운동의 시간에 따른 진폭변화를 비교하고 있다. 본 계산에서는 성긴 격자를 사용하였다. 일반적 으로 대진폭 운동이 아닌 경우 파 진동수에 따른 선체의 운동 은 선형특성이 지배적으로 파고의 증가에 따른 배수만큼의 운 동진폭의 증가 현상이 본 결과에도 나타나고 있다.

Fig. 16은 앞서 계산한 FPSO 운동의 RAO를 포텐셜유동 해석 결과 비교하고 있다. 그림에는 선체의 전후동요를 구속한 경우 의 결과를 포함하고 있다. 파 진동수 0.4 에서 전진동요와 종동 요 운동이 그리고 진동수 0.6 에서 상하동요 운동이 포텐셜유동 의 결과와 다소 차이를 보이는 것 외 각 파 진동수에 대해 모든 격자조건의 결과들이 비교적 만족스런 일치를 보여주고 있습니 다. 전후동요를 구속하였을 때 상하동요의 경우 큰 차이가 없고 낮은 파 진동수의 종동요 운동이 전후동요를 고려했을 때보다 


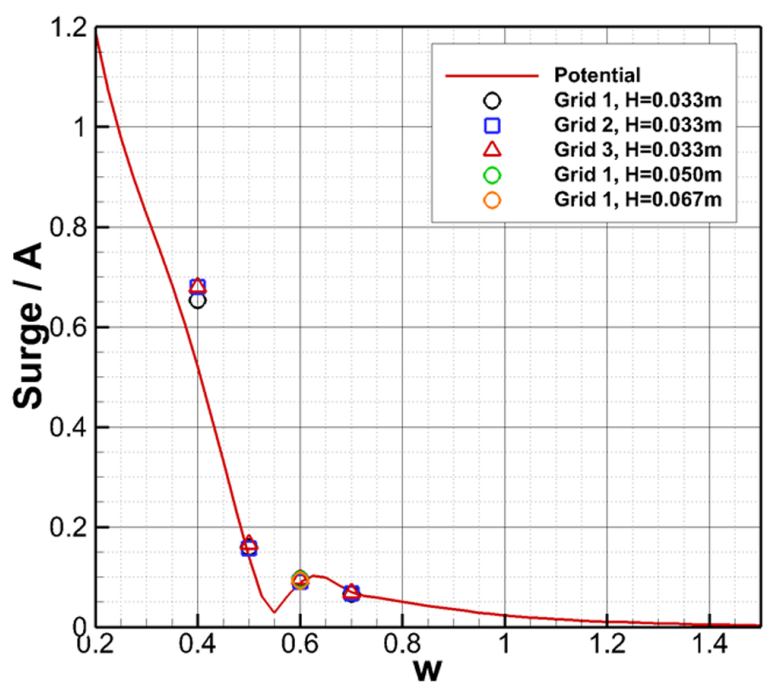

(a) Surge

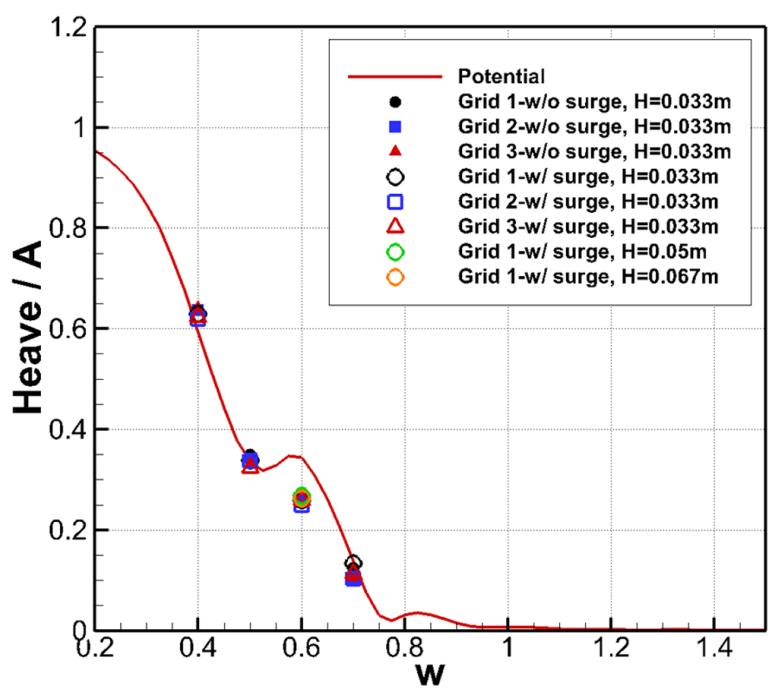

(b) Heave

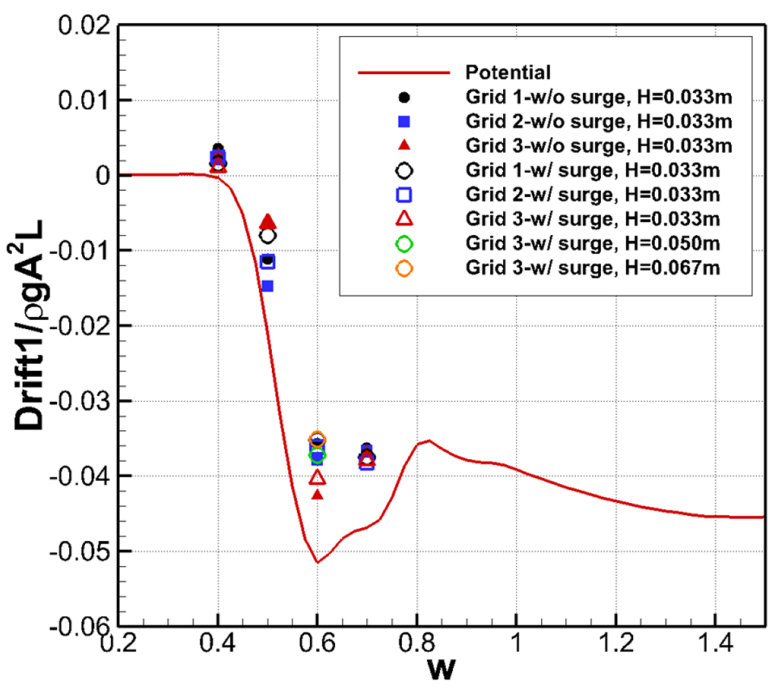

(c) Pitch

Fig. 16 Comparison of motion RAOs

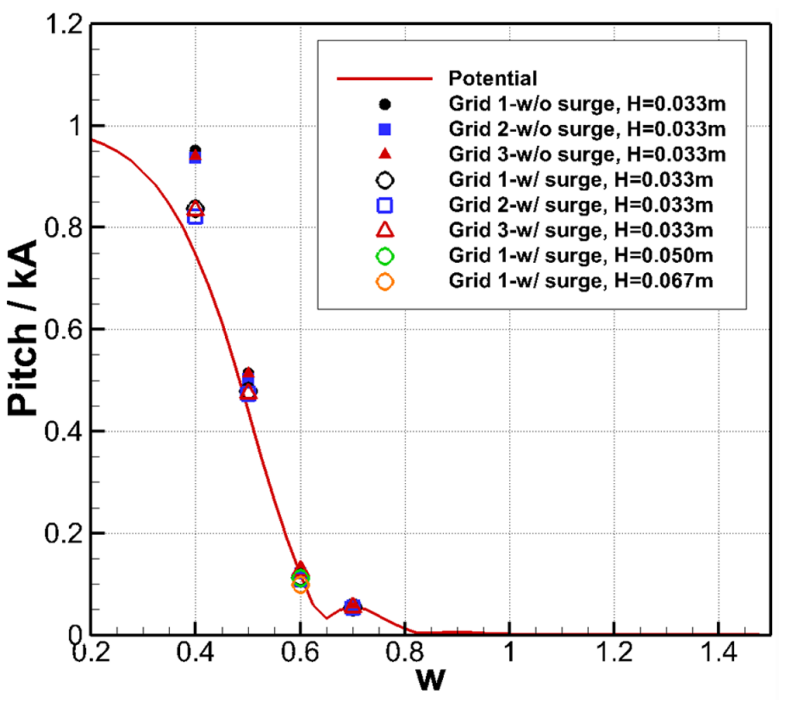

Fig. 17 Comparison of mean drift force RAO

커지는 것을 볼 수 있다.

Fig. 17은 전진동요 방향으로 선체에 작용하는 시간 평균한 표류력을 포텐셜유동의 해와 비교하고 있다. 본 수치해석의 경 우 포텐셜유동 해석보다 다소 작게 예측되고 있다. 이는 파와 선체가 상호작용하는 선체 근방의 유동이 두 수치해석법에서 다른 것이 그 원인으로 추측된다.

\section{4. 결 론}

본 논문의 2차원 파 진행문제에 대한 수치 민감도 해석을 통 해 파 시뮬레이션에 참조될 수 있는 수차격자 및 CFL조건에 대 한 수치오차 분포도를 완성하였다. 파진폭 및 파장의 오차는 파 장당 격자수 80 개 이상에서 많이 감소하였으며, 이보다 큰 파장 당 격자수 95 개 이상에서 $\mathrm{CFL}$ 조건에 따른 오차 폭이 대체로 작았다. 파고당 격자수의 경우 파장당 격자수 조건이 충분할 경 우 15 25개의 범위에서 적절한 정확도를 보였다. 이러한 수치 민감도 검토 결과를 바탕으로 대상 파가 아닌 파장과 파고가 서로 다른 파들에 대한 별도의 검증을 수행하여 파의 진폭과 위상에 대한 오차가 적은 해를 구할 수 있었다.

마지막으로, 2 차원 문제에서 얻은 수치 민감도 분석결과를 다 양한 파 진동수 조건의 파랑중 $\mathrm{FPSO}$ 운동해석에 적용하여 그 유효성을 확인하였다. FPSO 운동해석을 위해 각 파진동수 조건 에 대해 세 가지 수치격자 조건들을 결정하였으며 그 결과 각 각의 격자계에 대한 운동응답이 포텐셜유동의 해 비교적 좋은 일치를 보이는 것을 확인하였다. 다만, 파의 기울기가 상대적으 로 큰 파 진동수 0.6 과 0.7 조건에서 각각의 진동수에 대한 세 가 지 격자중 대체로 전체 격자수가 작은 격자계의 운동의 시계열 거동이 다른 파 진동수의 결과와 비교했을 때 격자간 다소 차 이를 보이는 것을 볼 수 있었다. 그러나 포텐셜유동과 비교하여 운동의 RAO들은 대체로 만족스러운 일치를 보여주었다. 선체 에 작용하는 전진동요 방향의 시간평균 표류력의 $\mathrm{RAO}$ 는 점성 을 고려한 본 수치해석 결과가 진동수 0.4 를 제외하고 포텐셜유 동의 결과보다 다소 작은 추정치 특성을 보였다. 
향후, 본 수치해석 결과를 바탕으로 구조물과 비선형파의 상 호작용이 큰 문제에서 높은 정도의 해를 얻기 위해 필요한 수 치 민감도 연구가 수행되어야할 것으로 판단된다.

$$
\text { 후 기 }
$$

본 논문은 SHI-KRISO 해양공학수조 활용 해양설계엔지니어 링 공동연구와 국제적 수준의 안전성을 확보한 GT 15,000 급 카 페리 설계 과제의 지원으로 작성되었습니다.

\section{References}

CD-adapco, 2015. STAR-CCM+ 10.04 Usre's Manual.

Enger, S., Períc, M., Monteiro, H.,2014. Coupling of 3D Numerical Solution Method Based on Navier-Stokes Equations with Solutions Based on Simpler Theories. Proceedings of XXXV Iberian Latin-American Congress on Computational Methods in Engineering, ABMEC, Fortaleza, CE, Brazil.

Go, G.S., Ahn, H.T., Ahn, J.H., 2017. Simulation-Based Determination of Hydrodynamic Derivatives and 6DOF Motion Analysis for Underwater Vehicle. Journal of Ocean Engineering and Technology, 31(5), 371-377.

Heo, J.K., Park, J.C., Kim, M.H., 2011. CFD Analysis of TwoDimensional Floating Body with Moon Pool under Forced Heave Motion. Journal of Ocean Engineering and Technology, 25(2), 36-46.

Hong, S.Y., Kim, J.H., Kim, H.J., Choi, Y.R., 2002. Experimental Study on Behavior of Tandem and Side-by-side Moored Vessels. Proceedings of 12th ISOPE, Kita-Kyushu 3, 841-847.

Kim, S.E., 2011. CFD as a Seakeeping Tool for Ship Design. International Journal of Naval Architecture and Ocean Engineering, 3(1), 65-71.

Nielsen, K.B., 2003. Numerical Prediction of Green Water Load on Ships. Ph.D. thesis, Technical University of Denmark.

Nam, B.W., Kim, Y.H., Yang, K.K., Hong, S.Y., Sung, H.G., 2012. Numerical Study on Wave-induced Motion of Offshore
Structures Using Cartesian-grid based Flow Simulation Method. Journal of Ocean Engineering and Technology, 26(6), 7-13.

Nam, B.W., Hong, S.Y., Kim, H.J., 2017. A Numerical Study on Slow-Drift Motion and Wave-in-Deck Impact Event of a Tension Leg Platform in Extreme Waves. Proceedings of the ASME 2017 36th International Conference on Ocean, Offshore and Arctic Engineering, Trondheim, Norway.

Muzaferija, S., Perić, M., 1999. Computation of Free Surface Flows Using Interface-tracking and Interface-capturing Methods, Nonlinear Water Wave Interaction, Mahrenholtz, O., Markiewicz, M., (Eds.), WIT Press, Southampton, UK, Chapter 2, 59-100.

Perić, R., Abdel-Maksoud, M., 2016. Reliable Damping of Freesurface Waves in Numerical Simulations. Journal of Ship Technology Research, 63(1), 1-13.

Park, I.R., Kim, J., Kim, Y.C., Kim, K.S., Van, S.H., Suh, S.B., 2013. Numerical Prediction of Ship Motions in Wave using RANS Method. Journal of the Society of Naval Architects of Korea, 50(4), 232-239.

Shih, T.H., Liou, W.W., Shabir, A., Zhu, J., 1995. A New k- $\varepsilon$ Eddy Viscosity Model for High Reynolds Number Turbulent Flows-Model Development and Validation. Computers and Fluids, 24(3), 227-238.

Sato, Y., Miyata, H., Sato, T., 1999. CFD Simulation of 3-Dimensional Motion of a Ship in Waves : Application to an Advancing Ship in Regular Heading Waves. Journal of Marine Science and Technology, 4(3), 108-116.

Yum, D.J., Yoon, B.S., 2008. Numerical Simulation of Slamming Phenomena for 2-D Wedges, Journal of the Society of Naval Architects of Korea, 45(5), 477-486.

Zhang, S., Liut, D., Weems, K., Lin, W.M., 2005. A 3-D Finite Volume Method for Green Water Calculation. 24th International Conference on Offshore Mechanics and Arctic Engineering, Halkidiki, Greece. 